\title{
Division and the City: Spatial Dramas of Divided Cities
}

\author{
Bölünme ve Kent: Bölünmüş Kentlerin Mekânsal Trajedileri
}

\author{
Gizem CANER
}

\section{ABSTRACT}

Every contemporary city is divided to a certain extent. The present study is concerned with urban division defined by extreme tensions related to nationality, ethnicity, religion, and culture, which are channelled into urban arenas. Once these contestations are made spatially visible, the "divided city" with which this study is concerned appears. Well-known examples of such "divided" cities are Belfast, Jerusalem, Nicosia, Mostar, Beirut, and Berlin. Due to distinctive attributes, these cities contain an exclusive discourse that differentiates them from other urban areas. In this context, the aim of the present study was to comparatively analyze urban consequences of division in selected case studies: Belfast and Berlin. As each city has unique attributes of geography, history, and economic development, the processes and outcomes of their division differ substantially. This investigation of the consequences of urban division in a temporal perspective presents patterns of urban development before, during, and after division in order to provide a comprehensive understanding of spatial dramas faced by these cities. Comparative analysis revealed a common pattern of functional and structural urban consequences, in spite of differences. It is suggested that an illustration of common patterns of development can facilitate an early recognition and management of division. It is believed that the findings of the present study will aid future studies that aim to understand the patterning of urban division and generate planning models to tackle problems faced by divided cities.

Keywords: Belfast; Berlin; divided cities; division, urban consequences of division; urban division.

\section{ÖZ}

Günümüz şehirlerinin neredeyse tamamı kavramsal bağlamda bir düzeye kadar bölünmüştür. Ancak bu yazı, milliyet, etnisite, din ve kültürle ilişkili uç gerilimlerin neden olduğu, daha spesifik bir kentsel bölünme türüyle ilgilenmektedir. Bu çatşmalar kentsel alanlarda ses bulmaktadır ve mekânsal görünürlük kazandıkları zaman, bu yazının da konusu olan 'bölünmüş kentler' ortaya çıkmaktadır. Bu şehirler arasında en iyi bilinen örnekler Belfast, Kudüs, Lefkoşa, Mostar, Beyrut ve Berlin'dir. Özgün niteliklerinden dolayı, bu şehirler, kendilerini diğer kentsel alanlardan ayıran özel bir söyleme sahiptirler. Bu çerçevede, bu yazının ana konusu, seçilmiş şehir örneklerinde-Belfast ve Berlin-bölünmenin kentsel sonuçlarının karşılaştırmalı olarak analiz edilmesidir. Her kent, kendine has coğrafi, tarihi ve ekonomik gelişme özelliklerine sahip olduğu için, bölünme süreç ve sonuçları büyük farklılıklar göstermektedir. Bölünmenin kentsel sonuçlarını süreç odaklı bir yaklaşımla değerlendirmek, bölünme öncesi, sırası ve sonrasındaki mekânsal trajedilerinin bütüncül olarak daha anlaşılabilir olmasına olanak tanıyacaktır. Karşılaştırmalı analiz sonucunda, örnek şehirler arasındaki farklılıklara karşın, genel bir fonksiyonel ve yapısal kentsel sonuçlar tablosunun ortaya çıktığı görülmüştür. Bu tablonun, kentsel bölünmenin mekânsal örüntüsünü anlamak isteyen ileriki çaIışmalar için aydınlatıcı olacağı düşünülmekte ve bölünmüş kentlerin karşı karşıya olduğu sorunlarla baş edebilmesi için geliştirilecek planlama modelleri için altlık teşkil etmesi beklenmektedir.

Anahtar sözcükler: Belfast; Berlin; bölünmüş kent; bölünme; kentsel bölünme sonuçları; kentsel bölünme.

Department of Urban and Regional Planning, Istanbul Technical University, Istanbul, Turkey.

Article arrival date: April 15, 2014 - Accepted for publication: September 29, 2015

Correspondence: Gizem CANER. e-mail: gizemcaner@gmail.com

๑ 2015 Yıldız Teknik Üniversitesi Mimarlık Fakültesi - @ 2015 Yıldız Technical University, Faculty of Architecture 


\section{Introduction}

Almost every major city around the world is heterogeneous in terms of culture and ethnicity. What this implies for cities is that division is commonplace and that every city is divided to a certain extent. Although many of these divisions are social, they have a geographical context since space is socially created. In other words, as Park (1926) states in his ground-breaking article 'The Urban Community as a Spatial Pattern and Social Order'; "social relations are so frequently and so inevitably correlated with spatial relations" ( $p$. 30 ), that social divisions frequently-and in some cases inevitably-manifest themselves physically. In this sense, it should be borne in mind that throughout this paper, division refers to a socio-spatial process.

For a better understanding of what is meant by the term 'division', we can consider Marcuse's (2002) assertions on types of division existing in contemporary cities. According to Marcuse, there are three types of urban divisions which can overlap or contradict each other;

- Cultural divisions: differences in language, ethnicity, nationality, religion etc. that are independent from economic production or power relations. Such differences may produce spatial segregation according to household type, family status, age and the like.

- Functional divisions: the result of economic logic, either physical or organisational, i.e. areas set aside for defence, commerce, and residence. Zoning is the accepted legal embodiment of such divisions.

- Status divisions: reflecting and reinforcing relationships of power, domination and exploitation. Class, income and occupation are some examples of divisions by status. In general terms, their spatial reflections are gated communities and slums.

This classification reveals how physical divisions emerge from non-physical ones. It also illustrates why division is the preferred term in this paper; because it refers to a broader concept than segregation. Here, division is used to evoke the meaning of segregation, which is "the spatial separation of various groups across different geographical areas" (Caves, 2005, p. 400). But more importantly, by preferring division to segregation, it is aimed to avoid the extensive segregation literature in order to stay focused on the extreme conditions of divided cities - the focus point of this paper.
A general literature review on the term 'divided cities' reveals a split between two distinct discourses. The first one, mostly developed from the 1950s to the 1980s, discussed divided cities through the common themes and conditions prevailing throughout the developed western world: divisions of capitalist production processes, urban segregation and increasing inequality between the affluent and deprived city districts (Safier, 1997). In the last three decades however, there has been a growing body of literature concerned with a more specific form of urban division, classified by its extremeness. This limited sense indicated physical or political contestations in a few special cases.

According to Anderson (2008: 6), "mainstream urban studies in English-speaking academia have generally concentrated on 'normal', 'undivided' and more or less peaceful cities [...] where these [ordinary] cities are considered 'divided', we have seen it is usually not by nationalism but by other divisions, such as ethnicity per se or social class".

The above excerpt implies that reasons of division are determinant in identifying which group a city belongs to. Processes like globalization, decolonization and neo-liberal restructuring form socio-economic differences in cities, often layered with ethnic differences. Status, class, welfare, power, race and ethnicity are the lines of division; hence, pluralist disputes are emphasized (Gaffikin and Morrissey, 2011). These cities-New York, London, Paris etc.-are usually referred to as 'multicultural', 'cosmopolitan' or 'global', and are believed to be easier to cope with since they are 'merely' divided (Benvenisti, 1986). On the other hand, most prominent processes behind division in 'extremely' divided cities are political and ideological oppressions like wars, as well as divide-and-rule strategies of the colonizers. In these cities, long-standing questions of identity, national sovereignty, territory, culture, language, and religion are to the fore, and they are usually layered with socio-economic differences. The presence of these undisputable aspects turns these cities into arenas of challenge by all means (for a detailed analysis about the reasons of division see Caner and Bölen, 2014).

Going back to Marcuse's (2002) classification of divisions, we can trace a complex overlap of cultural and economic divisions in both merely and extremely divided cities. Apparently, the severity of these divisions depend on their historical evolution, and in return, their physical manifestations range from acceptable levels of segregation to extreme levels of division. 
This paper is mainly concerned with the latter, extremely divided cities. More specifically, the aim is to observe their formation (how and why these cities become divided) and how this formation influences their physical structure (urban consequences and physical manifestations of division). In this framework, two case studies are chosen to monitor the evolution and consequences of socio-spatial division: Belfast, which has been divided for almost half a century and so remains; and Berlin which has been reunited for quarter of a century following three decades of division. Evidently, division is acknowledged as a gradual process that incorporates the transition of a divided city into a reunified one. Assessing each city's urban development patterns via their phases of division (pre-division, division, post-division or reunification) helps to capture this evolutionary perspective. In this paper, for each city, functional (administrative, residential, commercial areas, etc.) and structural (transportation network, infrastructure, figure-ground ratios, etc.) urban patterns are analysed for every division phase. As a conclusion, urban consequences of division are presented through deriving similarities and differences between these functional and structural urban patterns.

It is hoped that by providing a better understanding of 'spatial dramas' faced by divided cities, a contribution is made for future studies which aim to manage urban division and generate planning models that tackle the problems faced by divided cities.

\section{Two Case Studies}

In the following, general facts regarding division in two relevant case studies are given before moving on to examine urban division as a process and as an ensuing physical formation. Apart from direct implications of division, other indirect forces which shape the urban structure, such as planning decisions are evaluated as well.

\section{Belfast}

\section{General Facts Regarding Division in Belfast ${ }^{*}$}

Conflict Parties: Catholics / Republicans / Nationalists against Protestants / Loyalists / Unionists

Name: Peace walls / Peace lines

Duration: 1969-1998 (The Good Friday Agreement). The city is, however, still divided.

Context \& Location: The two opposing parties are in a religious, ethnic and nationalistic conflict, where

\footnotetext{
* Adapted from Calame and Charlesworth, 2009.
}

these differences are also layered with socio-economic cleavages. The importance of religion has diminished, causing Belfast's conflict to be labelled as ethno-national.

The walls are built at interfaces between the two communities, in direct response to chronic episodes of violence. They are predominantly at the North and West of the city, dissecting residential areas and in some cases, green areas.

Size \& Materials: Largest peace walls are $12 \mathrm{~m}$ high and $1.6 \mathrm{~km}$ wide. Smallest ones are $3 \mathrm{~m}$ high and $30 \mathrm{~m}$ wide. Typical materials are brick, concrete, iron railing, steel, barbed wire, and open wire mesh.

Permeability: Most peace walls are impermeable throughout their length. However, they are open-ended and do not provide a complete seal around residential enclaves. Some have gates which are either controlled by the police or by local residents.

Actors: First peace walls were constructed spontaneously by residents themselves. In time, these disappeared altogether and were replaced by more definitive walls, built and paid by the municipal government. The process to build a new wall is initiated by community representatives who can justify their reasons for the erection or extension of a peace wall. If accepted by the Parliament, the wall is built according to normal building codes and practices (contract, bidding etc.).

Status: The Belfast Interface Project identifies 99 different security barriers and forms of defensive architecture across the city as of 2013 (Url-1).

\section{Pre-Division}

Ethnic conflict in Belfast has its roots in the 17th century when the British decided to establish a colony on the island by a process known as the Ulster Plantation. The newcomers (Protestants) walled themselves to form what the natives (Catholics) perceived to be "pockets of civilization" (Jones, 1960).

With the industrialization boom of Belfast in the 19th century, labour demand was mainly met by the Catholics living in the hinterland (Boal, 1996; Jones, 1960). As a result, even though Catholics started to reside within the walls, they started living relatively clustered in their own residential environments. By clustering linearly on the axis of the Falls Road, they formed the Catholic working class area of Belfast. Similarly, working class Protestants started settling in the north, along the Shankill Road. These clusters are still visible in the city (Figure 1 ). 
The mainly ethnic and religious division took a nationalist form by the second half of the 19th century when Catholics started to voice their demand for Irish independence, and Protestants for union with Great Britain (Boal, 2002). Disturbances began to occur in the streets of Belfast. A new political label was added to the old ones; Catholics were from now on also referred to as Republicans and/or Nationalists, whereas Protestants were also called Loyalists and/or Unionists. As a result, in 1921, Ireland seceded from the United Kingdom, while only Northern Ireland with its capital Belfast, which was predominantly Protestant, was granted regional autonomy. Consequently, segregation increased gradually during the 20th century.

\section{Division}

The period between 1969 and 1998 is referred to as 'The Troubles', when more and more clashes between Catholics and Protestants took place in the streets of Belfast and the conflict reached its peak point. In this time interval, around 60,000 people relocated into neighbourhoods with people of their own 'kind' (Brand, 2009a). As concentration of each ethnic group increased, the boundaries between the two groups became well defined and symbolically more important. These boundaries turned into interface areas which were flashpoints of social tensions.

In August 1969, when riots led to fighting along Falls

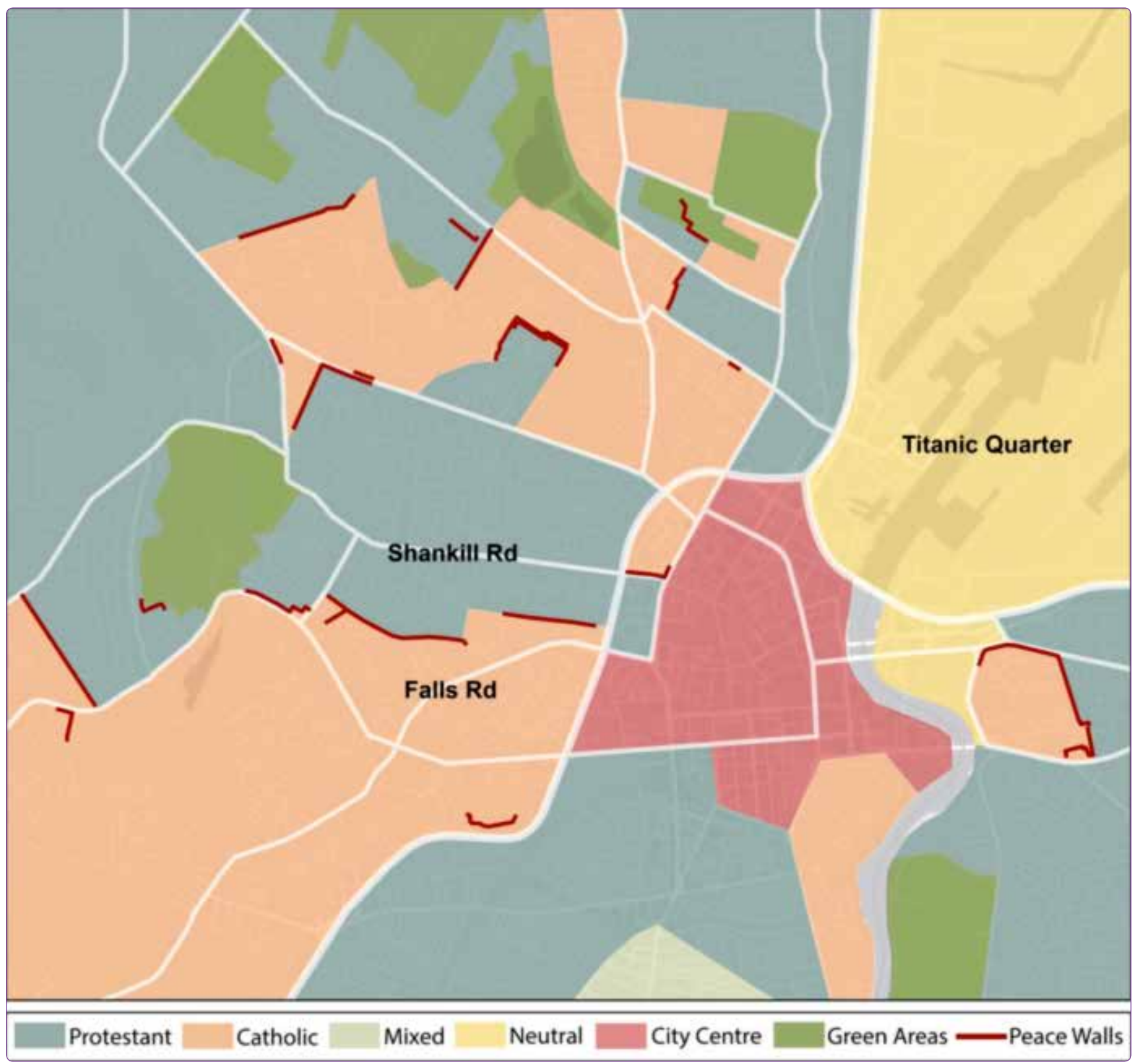

Figure 1. Residential clusters and peace walls of inner city Belfast, 2015. 
Road and violence broke out at interfaces, Catholic residents who felt trapped and besieged, anxiously built physical barricades from all sorts of material they could find, mainly along the perimeters of their enclaves. When British army units were sent to secure volatile areas, they embraced the idea of building modular constructions in order to minimise or even eliminate conflict between the opposing groups. These makeshift walls are controversially named as 'Peace Walls'. There is a clear contradiction in the phrase, illustrated in the opposition of the words 'peace' and 'wall'. Even though they were intended to be temporary, these walls still remain and many others have subsequently been added to the urban fabric.

\section{Urban Consequences of Division}

Even though the Good Friday Agreement was signed in 1998 , it did not bring solutions to the problems arising from the fractured structure of the city, or to the problems of everyday life within. The urban arena of Belfast today is still a hyper-segregated one with strict sectarian territoriality (Bollens, 1998). In 2001, around half of the city's population lived in wards that are $90 \%$ Protestant or $90 \%$ Catholic community background (Gaffikin and Morrissey, 2011).

According to a 2011 census, Belfast's population is 280,962 , of which 48.6 per cent is Catholic and 42,3 per cent Protestant. Figure 2 illustrates the distribution of

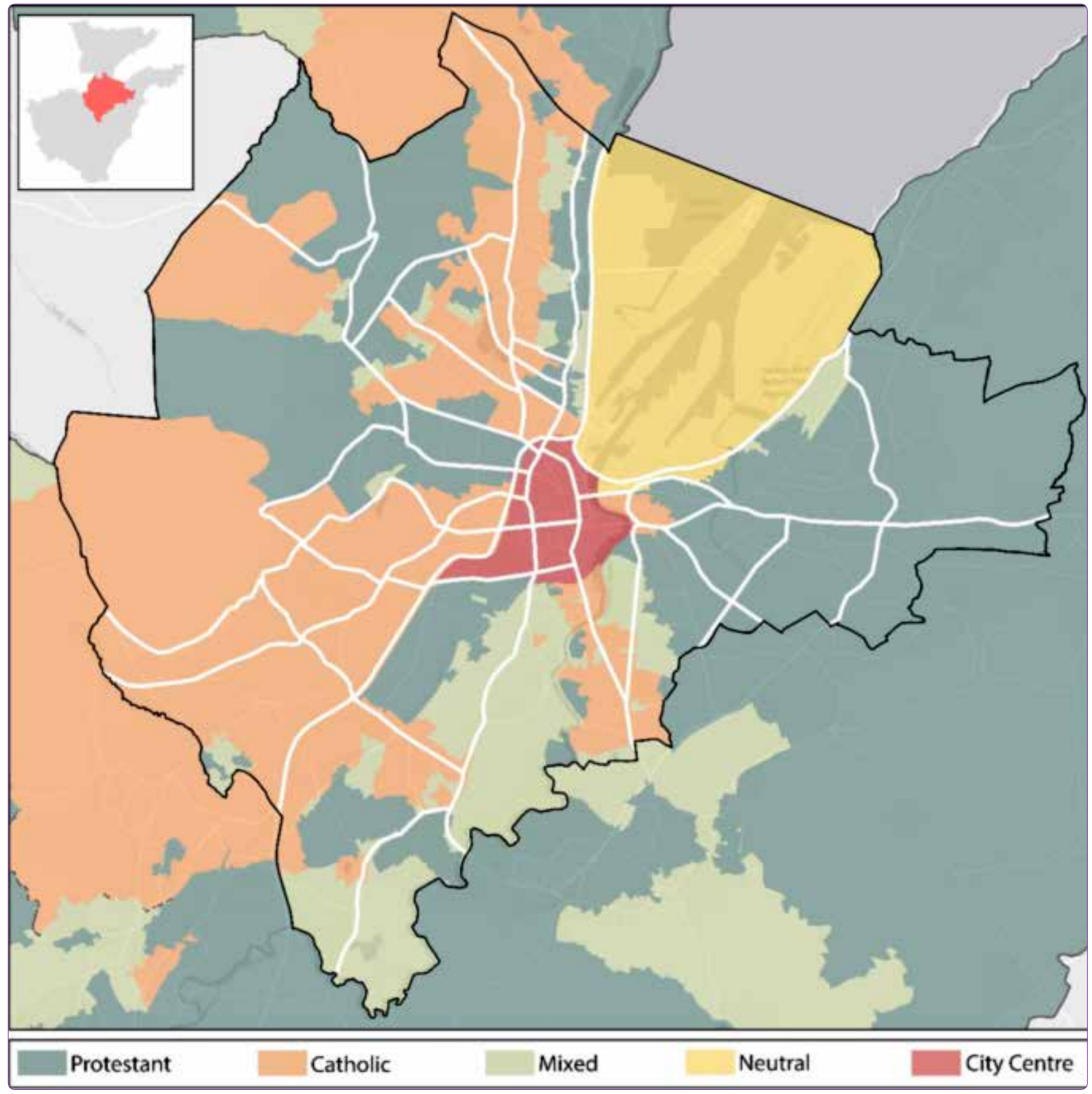

Figure 2. Physical appearance of division within Belfast City Council limits, 2015. 
these groups within the Belfast City Council area. The map reveals that most segregated neighbourhoods of Belfast are to the north, west, and east-which have historically developed in this way-and mixed neighbourhoods are to the south where suburban development is oriented.

Gaffikin et al. (2008) designate four main functional zones in modern-day Belfast: 1| Ethnic space: segregated residential communities (for example, clusters around Shankill and Falls Roads; see Figure 1). 2| Neutral space: based largely in the city centre and waterfront, they are safe spaces open to both communities for employment, leisure, shopping and residence (Figure 1). 3| Shared space: spaces where not just contact, but also engagement is possible (for example, integrated schools and Queen's University). 4| Cosmopolitan space: spaces that have an international character with no reference to division. They are usually new spaces, referred to as "showcase areas", meaning that they are showcasing Belfast as a 'normal' city. (Examples are 'New spaces' such as the Titanic Quarter along the waterfront, or 'old spaces' like the City Hall.)

As an outcome of a long-standing tendency of people seeking safe, homogeneous areas populated by people of their own kind, inner-city residential areas became havens for working-class communities, suffering from a low quality urban environment. Gaffikin and Morrisey (2011) found a clear connection between segregation and deprivation: according to them, most deprived areas are in segregated, homogeneous - either Catholic or Protestant - zones. As mentioned be- fore, these segregated areas are concentrated in many parts of North, West, and East Belfast. The residents of the southern part of the city, however, are affluent and, even though these affluent Catholic and Protestant residents are spatially mixed (see, Figure 2 ), they are socially separated (Brand, 2009a).

Another result of persistent division is the duplication of certain urban functions. Particularly in most segregated areas, social infrastructure, such as hospitals, schools, religious compounds and leisure services are duplicated. Each community builds their own institutions to meet their needs.

Although Belfast retains its capital city functions (such as administrative capacity), the city's prestige is under strain. This is why the urban government showcases Belfast as a normal, global city to invest in via creating totally new functional zones such as the Titanic Quarter. However, such interventions have to be well-advised in order to eliminate the risk of collision of incompatible functions.

The contemporary urban structure of the inner city has been shaped by major road infrastructure programs and comprehensive redevelopment that started in the 1960s and is still on-going (Hackett et al., 2011). For instance, the new Westlink Motorway cut a path through working class housing areas and became a barrier between Catholics and Protestants. Another problem regarding transportation infrastructure is the increasing presence of cul-de-sacs since the 1980s (Figure 3 ) due to the eradication of peace walls.

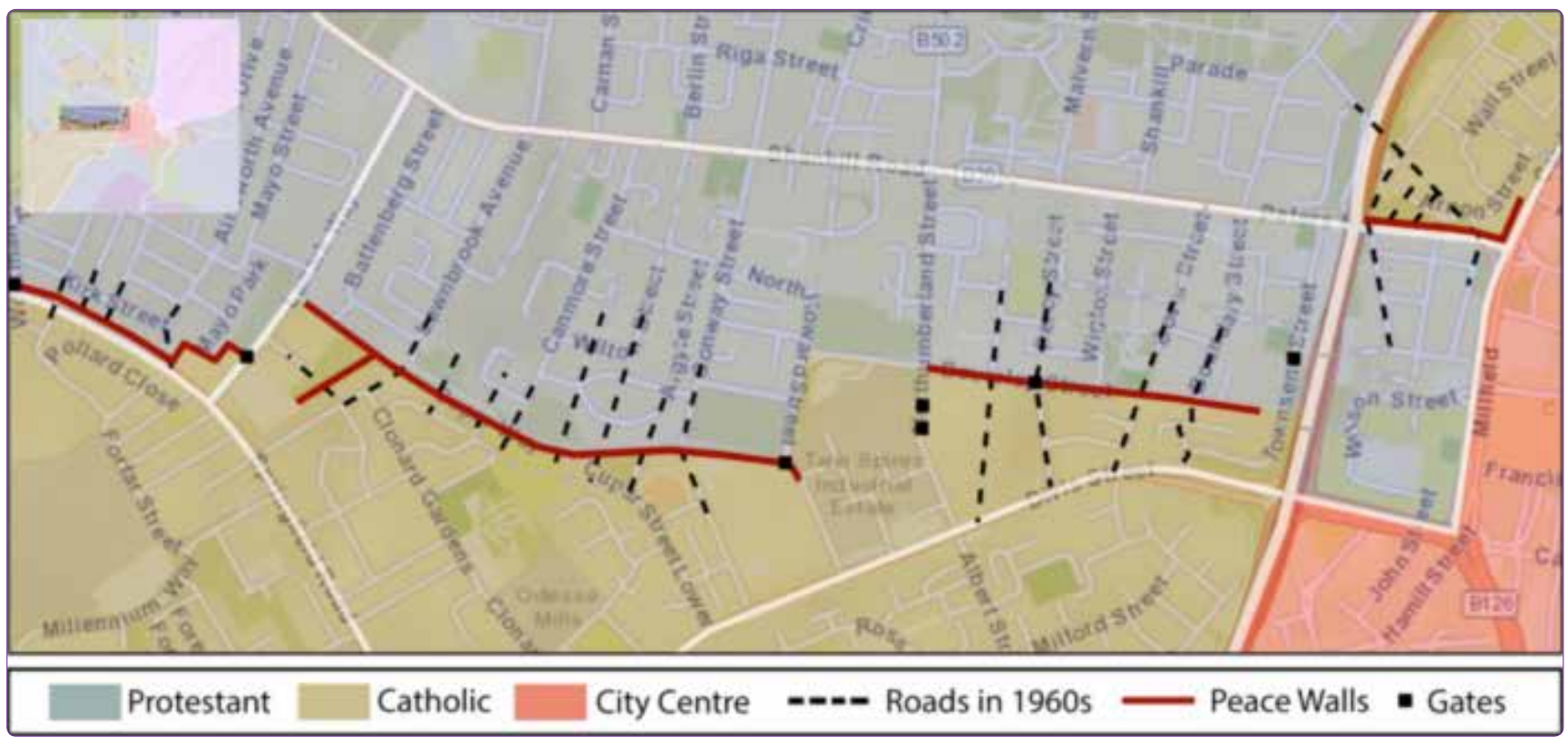

Figure 3. Disconnected roads in residential areas, Belfast, 2015. 
Furthermore, car-dominance in the city caused the emergence of spacious car parks, contributing to the increase of vacant and derelict land near the inner city. Figure-ground ratios have changed drastically over recent years. Very frequently, there are spacious car parks, which support car-domination within the city and render pedestrian connections inadequate.

Perceived threat in the city raises the issue of safety as a prominent subject. One measure employed against these concerns is the creation of "caged houses" (Figure 4), where individuals "cage" their houses with bars and grills over gardens for protection against flying stones and the like.

Physical environment is transformed into communal regions by the use of symbols. Murals are the most visible artefacts of territorial ownership. Curb stones are also transformed into territorial markers through redwhite-blue or green-white-orange paint in many Unionist or Nationalist areas. Flags, being cheap and easy to display, are also used for strengthening belonging. Figure 4 represents examples of territorialisation in the city.
The bitterest artefacts of division without dispute are the Peace Walls. Ninety-nine peace walls exist in Belfast today, some as high as ten meters and sometimes several kilometres long. Some have gates which can be closed at specific times of the day (Figure 3); some are operated by the police, some by adjacent communities (Brand, 2009b). These walls are usually built upon request of the residents living near interface areas. Recently, they have been painted by graffiti artists around the world to create a tourist attraction, but as Brand (2009a) implies, beautification legitimizes their existence. Peace walls are the scars of conflict on the urban form of the city, appearing suddenly and unpredictably, interrupting roads/parks, and shaping daily movement patterns of local residents drastically.

\section{Berlin}

\section{General Facts Regarding Division in Berlin}

Conflict Parties: USA, UK and France / Federal Republic of Germany (FRG) / West Germany against USSR / German Democratic Republic (GDR) / East Germany
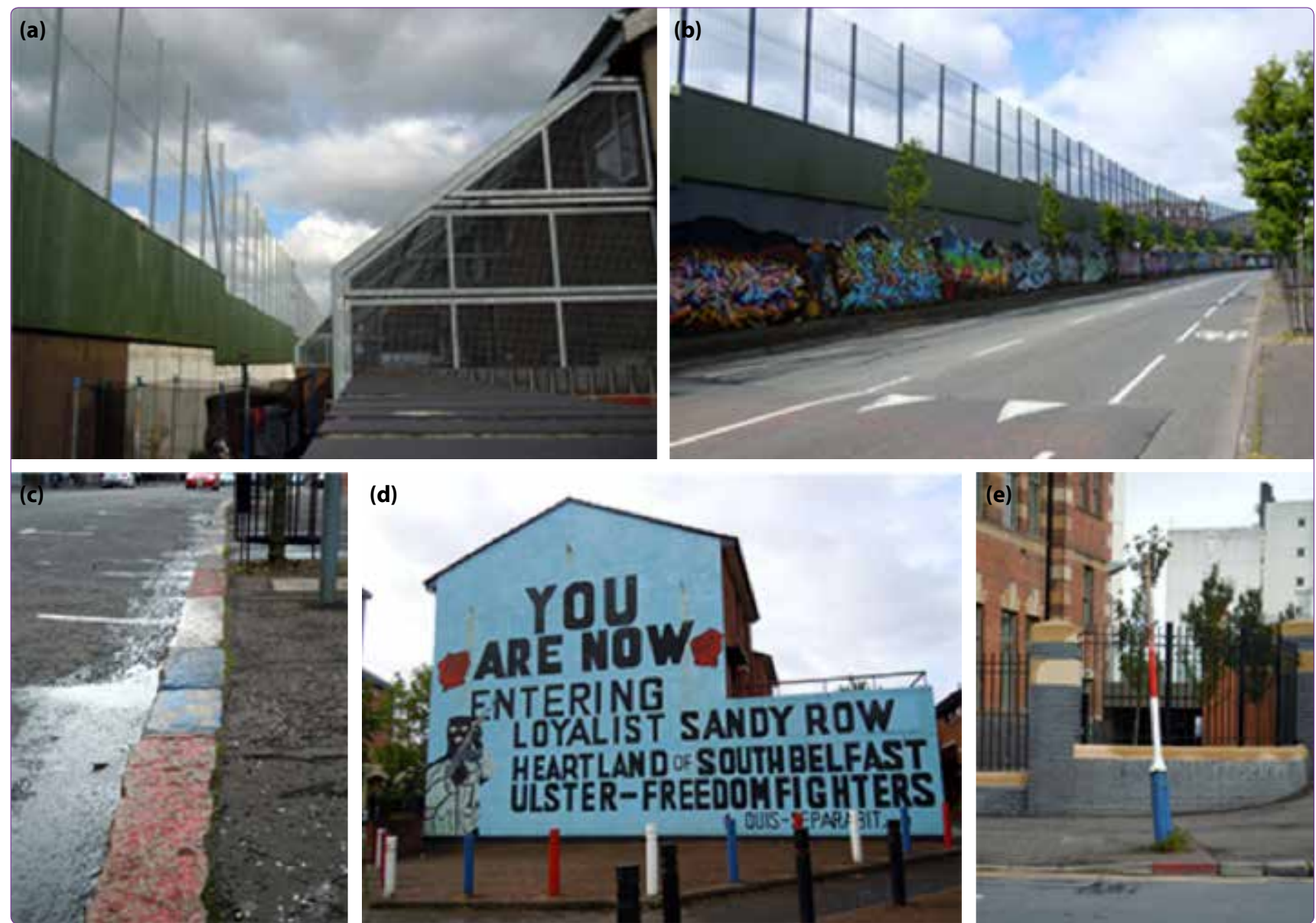

Figure 4. Markers of division in the city: (a) caged houses along peace walls; (b) peace walls (Cupar Way); (c) coloured curb stones; (d) murals; (e) sign posts (photos by the author). 
Name: The Berlin Wall

\section{Duration: 1961-1989}

Context \& Location: Berlin's division was due to an international war (WWII), in other words a political conflict, where ideological viewpoints of west vs. east and capitalism vs. socialism were also played out.

In order to cut off brain drain from East Germany to West Berlin, the Soviet Sector initially built temporary barriers. In time, these were replaced by concrete walls under the GDR authority. In the years to come, the barriers were modified, reinforced, and further expanded, and the system of controls at the border was perfected. Eventually, the USSR completely sealed off West Berlin by erecting the Berlin Wall all around it and rendering West Berlin an island in East Germany. The Wall cut through the exact centre of the city of Berlin.

Size \& Materials: The Berlin Wall was $155 \mathrm{~km}$ long in total, of which $43 \mathrm{~km}$ separated East and West Berlin through the city centre. It was $3.6 \mathrm{~m}$ high in some places. No man's land separating the two sides ranged from five metres to several hundred meters.

Across the years, The Berlin Wall evolved through different versions: wire fence (1961), improved wire fence (1962-1965) and concrete wall (1965-1989). The wall was reinforced by mesh fencing, signal fencing, anti-vehicle trenches, barbed wire, dogs, beds of nails, over 302 watchtowers, and 20 bunkers.

Permeability There were a total of 8 checkpoints between East and West Berlin and 6 between GDR and West Berlin to be used by West Berliners, citizens of the FRG, and foreign nationals. East Berliners and GDR citizens were not permitted to cross the border.

Actors: The Berlin Wall was built by East Germany, the GDR authority.

Status: The Wall was dismantled in 1989, with only certain parts of it remaining today to be used for touristic purposes.

\section{Pre-Division}

The division in Berlin resembles an ideological separation caused by political oppositions, rather than ethnic, national or religious ones often encountered in other divided cities. Hence, Berlin constituted one entity until it was divided in 1945.

\section{Division}

After the Second World War, Berlin was forcibly separated into West (UK, USA, France) and East (Soviet Union-SU) sectors following the trajectory of the whole country's partitioning. West Berlin was an exclave in the Soviet territory, with road, air and rail connections to West Germany (Figure 5).

After the Berlin Blockade of 1948-1949, quarrel between East and West Germany culminated in the setting up of two rival states; in Western Germany the Federal Republic of Germany (FRG), comprising the American, British, and French Zones, and in Eastern Germany the German Democratic Republic (GDR), comprising the Soviet Zone. GDR declared East Berlin as its capital, while FRG carried its capital city to Bonn.

The sealing off of the border was a gradual process which first appeared in 1952. GDR was approaching an economic collapse, and people of the East were trying to escape from the impact of this by fleeing to West Berlin (Elkins et al., 1988). In 1961, to restrict movement The Berlin Wall was erected and armed by military and police forces of the GDR (Figure 6).

\section{Urban Consequences of Division}

Immediately after 1961 roads were torn apart, rail systems were separated, and a full defence depth was erected with alarmed wires, dogs, watch-towers, etc. (Figure 7). In order to erect the wall, buildings were

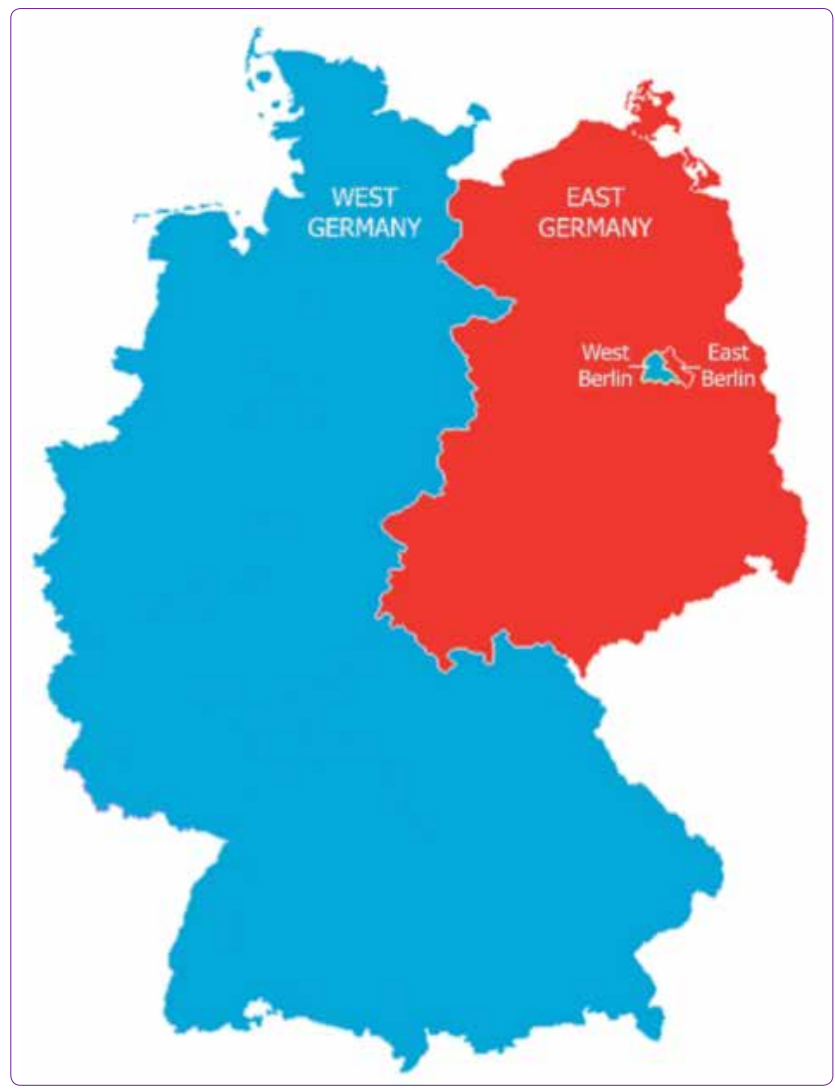

Figure 5. West-East Germany and West-East Berlin during 19451989. 


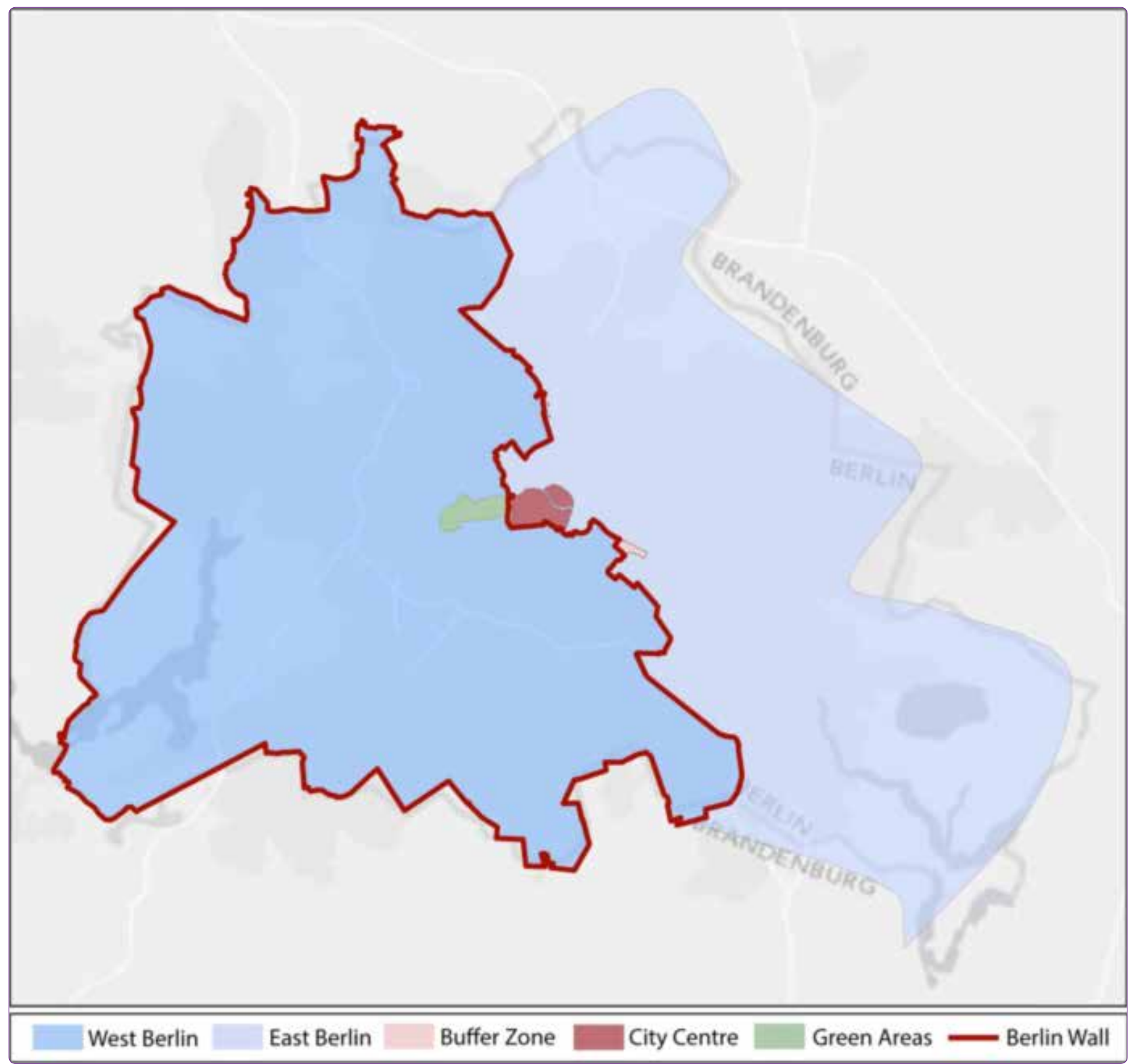

Figure 6. Berlin and Berlin Wall during division, 1961-1989.

demolished along its route, usually involving a single street of structures, but sometimes encompassing entire blocks (Loeb, 2006).

In West Berlin, urban development opportunities were restricted due to limited available land. Therefore, in the first phase of division, during the 1950s, reconstruction projects were implemented in the built-up area. Even though the Eastern sector did not have an urban expansion problem, lack of funds and building material, combined with strict planning policies helped to contain the urban sprawl (Von Beyme, 1990). Consequently, both halves of the city evolved compactly. During the second phase of division, between the 1960s and 1970s, growing demand for housing was dealt with construction of massive, high density housing areas on the outskirts of the city in West Berlin. In the Eastern sector, there were also major urban extensions. Again, the result was the development in effect of the two sides of the city in a mutually compatible way.

The historical city centre (Mitte) and the Central Business District (CBD) on the north-east axis (Friedriechstrasse) remained in the East (Figure 8). But this commercial axis was treated as any other street 


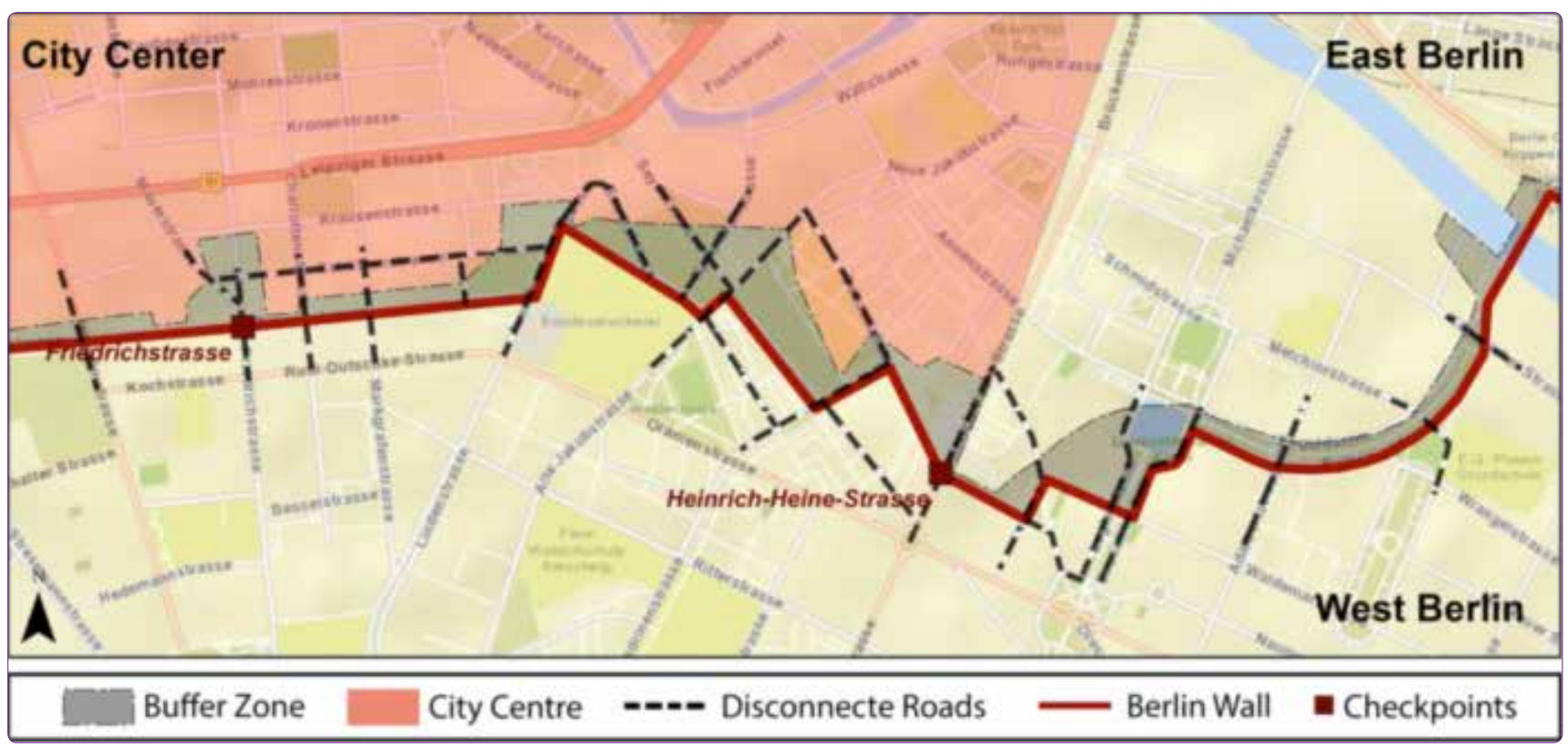

Figure 7. Disconnected roads in the city centre during division, Berlin, 1961-1989.

in the anti-market GDR, and the CBD was further developed in Alexanderplatz. West Berlin had to develop a new CBD around the Zoo rail station which was already a secondary commercial centre before division with shopping and entertainment functions. During the years of division a hierarchy of central places developed in West Berlin (Ellger, 1992), making this part of the city polycentric.

Meanwhile, a concentric structure was taking shape on the East side (Schwedler, 2000). East Berlin had the advantages and central functions of a capital. It housed all government institutions, top party bureaucracies, headquarters of industrial conglomerates and embassies (Ellger, 1992). In the FRG, the capital was moved to Bonn, giving a disadvantageous position to West Berlin in this respect.

The dual landscape of the city was accentuated by infrastructural dissociations. Only the sewage treatment plant in East Berlin served for both parts of the city. There was also collaboration in matters of water infrastructure. Most severely affected was the transportation network, which was split up and developed in different directions. Traffic played a smaller role in the GDR than the West; the huge magisterial roads were sufficient (Von Beyme, 1990).

In West Berlin, land use plans (FNP) developed during years of division were made as if no boundary existed. The context of the surrounding GDR was included in pale grey, and major routes that would be reconnected following reunification were indicated by dashes in a light tone (Loeb, 2006). Construction that would impede a future reunification was not permitted. Contrarily, plans of the Eastern side showed no trace of West Berlin.

\section{Reunification}

Almost 45 years of division ended in 1989 with the end of Cold War. Destruction of the wall started rapidly and works to unite the city socially, physically, economically and politically has carried on up to date.

Since reunification, planning process of the city is shaped by a doctrine which came to be known as 'Critical Reconstruction'. This approach to planning is "a critical re-appropriation of the past's particular urban virtues" (Murray, 2003: 4). The emphasis is given to pre-1914 history (Marcuse, 1998).

Berlin's planning activity has since been focused on three main themes: $1 \mid$ physical reunification; $2 \mid$ reestablishment of Berlin as the capital; and 3| showcasing Berlin to create a global city. Specifically the final theme resulted in a number of large projects which are centred in the inner city. These projects have been criticized for creating a segmented city, and being under the drive solely of the private market (Marcuse, 1998). A well-known example of such projects is the Potsdamer Platz.

On the other hand, the one-time presence of the Wall is acknowledged in all the plans that have been produced after reunification. The main consideration is to preserve the memory of the Wall (Figure 9) by lo- 


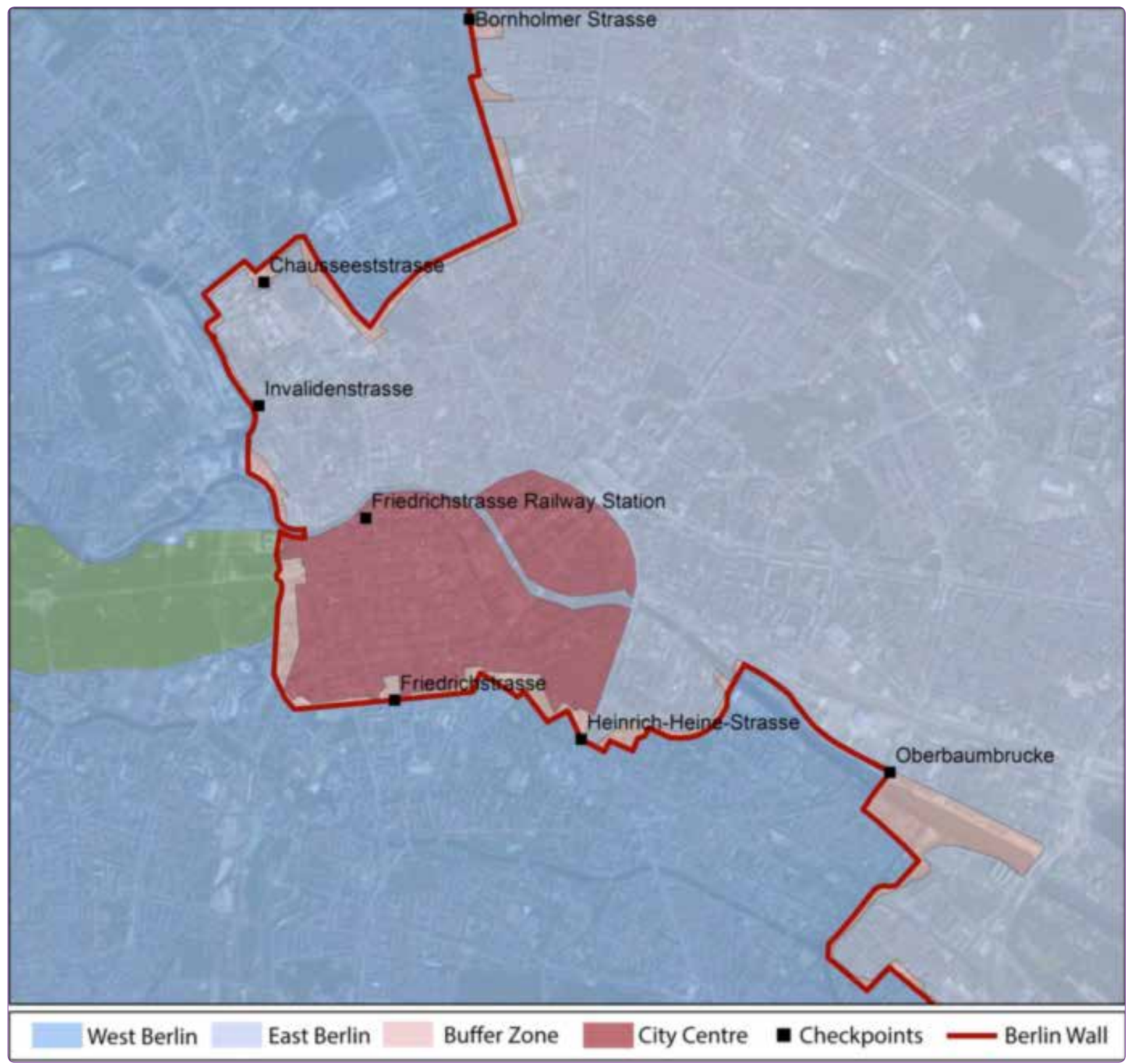

Figure 8. City centre during division, Berlin, 1961-1989.

cating landmarks, leaving walkways and bicycle paths along the border strip, and preventing temporary uses along the border zone. A report developed in 2000 by the City Development Office elucidates the significance of the Wall and opportunities it offers for future development of the city as a unity (Loeb, 2006). The report gives details about how the acquired land from the former Buffer Zone has been used since reunification:

"By far the largest amount of freed land was devoted to green spaces and recreational areas (38\%), while streets account for the second largest (25\%). Buildings account for $20 \%$ of the new land area, while the rest is part of the canal and river (11\%) or mass-transit (6\%) systems." (Loeb 2006: 80).

\section{Results and Conclusion}

Analysis of the case studies reveals that different historical processes inevitably produce different types and physical manifestations of division. Investigating division in phases has been helpful in differentiating the causality of the case study's current circumstances. Belfast was not divided by a war but a colonization process which caused each group to unite internally and, therefore, produce the oppositions which led to division from within the social structure of the city. 

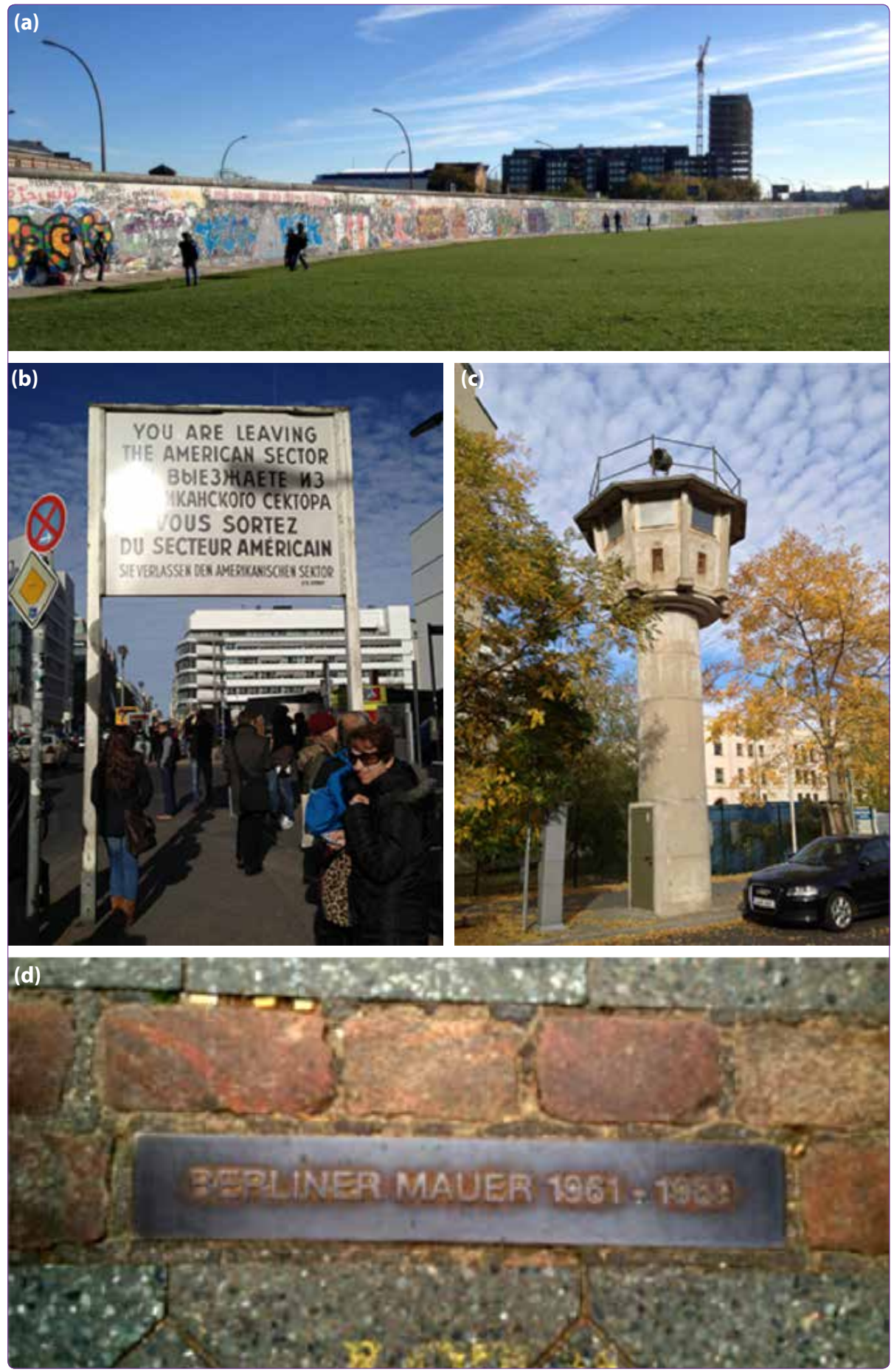

Figure 9. (a) East Side Gallery, preserved $1.3 \mathrm{~km}$-long section of the wall; (b) a preserved sign post at Checkpoint Charlie; (c) a watchtower; (d) a sign showing the former route of the wall (photos by the author).

And because here division developed in a long timespan as an internal process, it still lingers. Berlin, like Belfast, was divided for a long period; however, there division was immediate (aftermath of an international war) and less penetrable (concrete walls instead of separation barriers). And when the political atmo- sphere eased and occupying powers drew back, reunification became possible since the people that were divided were not the ones who wanted the division in the first place.

Results of the analysis of urban consequences of di- 
Table 1. Urban consequences of division

\section{Structural consequences}

* Inefficient and restricted transportation network.

* Dissociations in infrastructural systems.

* Appearance of different urban development patterns.

* Road-dominated environment and minimised pedestrian network.

* Proliferation of cul-de-sacs and vacant land, specifically in the city centre; while the city carries on to expand to its suburbs.

* Presence of frontier landscape, waste of land in the heart of the city.

* Deterioration of buildings. Appearance of deprived city districts; specifically near border zones.

* Everyday artefacts of division which hinder daily life in cities.

\section{Functional consequences}

* Declining central functions of the urban core.

* Fading primacy of capital city administrative functions, losing decision making capacity and prestige of the city.

* Formation of ethnically homogeneous, segregated residential areas, 'ethnic enclaves'.

* Bi-polarization of commercial areas.

* Duplication of urban functions (transportation, services etc.).

* Changing and colliding functions of urban space.

* Territorialisation renders certain areas to be functional only for certain parts of the population.

vision are manifold. For a better understanding, we can discern them as structural and functional consequences. In the results, first the structural consequences are narrated, then the functional ones.

Berlin was divided through the heart of the urban core, whereas Belfast's division is scattered all around the city. Furthermore, peace walls in Belfast do not have a military presence as the Berlin Wall had. But all in all, the dividing lines turned streets into cul-de-sacs via walls, barbed wires, sandbags, wire meshes, steel and the like.

As we have seen in Berlin, when the city is divided in the middle, the two halves have restricted options for growth. The traditional pattern of urban sprawl is hindered where each side can only advance on available routes. In addition, different developmental patterns could be observed: West Berlin had a hierarchy of centres, East Berlin continued to grow concentrically.

Deterioration of the buildings near the border was not only because of war damage, but also due to vacation of the buildings following population exchanges. In Berlin, a further consequence has been derelict industrial buildings due to a lack of finance (East Berlin) or incompetence (West Berlin). Also, in war-torn cities like Berlin, buildings are demolished to give way to military border zones. This resulted in vacant lands proliferating near border zones, especially after reunification. On the other hand, vacant lands in Belfast were mainly formed due to new road projects.
The most visual artefacts of division are territorial markers used to exert influence on people's perception and behaviour. Belfast is a fruitful area for the study of artefacts of division. Murals, flags, curb stones are only some elements reflecting territorial claims through the usage of urban artefacts.

Functional consequences of division can be summarised as follows:

- The central functions of the urban core were lost; especially due to extensive war damage (Berlin).

- Commercial areas moved away from the dividing line and bi-polarized (Berlin).

- The primacy of Berlin as a capital faded away during years of division, due to political instability. Belfast preserved its capital functions but the prestige of the city diminished due to sporadic violence.

- Residential zones in both cities became ethnically homogenized due to population movements and displacements.

Intersection points of residential zones were the most vulnerable areas of conflict, and either barricades were erected (as in the case of Belfast peace walls), or they turned into derelict sites. People who had the opportunity moved out of these areas for safer locations, and low status immigrants, refugees or homeless people occupied the empty houses. As a result, residential 
segregation coincided with socio-economic cleavages, further reinforcing divisions.

The diseconomies of division can be easily comprehended from the analysis. First, because these cities lose their hinterland they become an 'end city'. Second, duplication of public facilities, services, transport systems and infrastructure means enormous waste of resources. Third, apart from the cost of disconnecting infrastructural systems, the cost to re-connect them is also enormous. Moreover, reunification in Berlin, where it was relatively easy to re-connect the infrastructure, showed that it is hard to reinstate a city which will function as a whole. In other words, social divisions tend to linger, hindering the city to be used freely and openly, even after physical reunification.

The results of the analysis show that in spite of differences among the two case studies, a common pattern of functional and structural urban consequences surface (Table 1). However, the fact should not be neglected that in each city division produces unique consequences according to its political, socio-economical and physical transformations. Hence, this list is a preliminary one and can vary depending on the subject and the choice of case studies.

In conclusion, it can be asserted that these consequences are spatial tragedies, which can ransack any city around the world. Reunification can turn physical downsides around only by spending large amounts of money. And even then, division lingers in the city until the communities can erase their tragic mental maps. To facilitate the erasure of tragic mental maps of divided city residents, urban planning should undertake the role of directing spatial dramas of a divided city in desired paths.

It is believed that the findings of this study will be illuminating for future efforts to understand the patterning of urban division and to generate planning models for tackling the problems faced by divided cities. Illustration of common developmental patterns of division will facilitate early recognition and management of this process. Hence, this study can contribute to future work aimed at developing effective planning approaches and management forms in divided cities.

\section{References}

Anderson, J. (2008) From Empires to Ethno-National Conflicts: A framework for studying "divided cities" in "contested states" - Part I. Divided Cities/Contested States Working Paper No.1.

Boal, F.W. (1994) "Encapsulation: Urban Dimensions of National Conflict". Ed.:
Boal, F.W. (1996) "Integration and Division: sharing and segregating in Belfast", Planning Practice and Research, 11(2), pp.151-159.

Boal, F.W. (2002), "Belfast: Walls Within", Political Geography, Vol. 21, No. 5, pp.687-694.

Bollens, S.A. (1998) "Urban Policy in Ethnically Polarized Societies", International Political Science Review, Vol. 19, No. 2, pp. 187-215.

Brand, R. (2009a) "Written and Unwritten Building Conventions in a Contested City: The Case of Belfast", Urban Studies, Vol. 46, No. 12, pp.2669-2689.

Brand, R. (2009b) "Urban Artifacts and Social Practices in a Contested City", Journal of Urban Technology, Vol. 16, No. 2, pp.35-60.

Calame, J. and Charlesworth, E. (2009) Divided Cities: Belfast, Beirut, Jerusalem, Mostar, and Nicosia. Philadelphia, University of Pennsylvania Press.

Caner, G. and Bölen, F. (2014) "Multiculturalism versus Divisin: Socio-Spatial Transformations and the City". Eds.: D. Mansour and A. Milne (editors) Negotiating Boundaries in Multicultural Societies. Oxford: Inter-disciplinary Press.

CRC-Community Relations Council (2008) Towards Sustainable Security: Interface Barriers and the Legacy of Segregation in Belfast. Belfast, CRC.

Elkins, D., Elkins, T.H., Hofmeister, B. (1988) Berlin: The Spatial Structure of a Divided City, Routledge, London

Ellger, C. (1992) "Berlin: Legacies of Division and Problems of Unification", Geographical Journal, Vol. 158, No. 1, pp.40-46.

Gaffikin, F. and Morrissey, M. (2011) Planning in Divided Cities, Chichester, Blackwell Publishing.

Gaffikin, F., Sterrett, K., McEldowney, M., Morrissey, M., Hardy, M. (2008) Planning Shared Space For A Shared Future, Research Report for Community Relations Council, Belfast.

Hackett, M., Hill, D., Sterrett, K. (2011) “Mapping And Repairing The Broken City: Belfast's Disjointed and Fragmented Urban Structure", Paper presented in Urban Conflicts: Ethno-national Divisions, States and Cities Conference. Queen's University Belfast.

Jones, E. (1960) "The Segregation of Roman Catholics and Protestants in Belfast" Ed.: Peach, C., (editor) Urban Social Segregation, 1975. New York, Longman, pp. 225-244.

Kliot, N., Mansfeld, Y. (1999) "Case Studies Of Conflict and Territorial Organization in Divided Cities", Progress in Planning, Vol. 52, pp. 167-225.

Loeb, C. (2006) “Planning Reunification: The Planning History of the Fall Of The Berlin Wall", Planning Perspectives, Vol. 21, No. 1, pp. 67-87.

Marcuse, P. (1998) "Reflections on Berlin: The Meaning of Construction and the Construction of Meaning", International Journal of Urban and Regional Research, Vol. 22, No. 2, pp. 331-338.

Murray, G.J.A. (2003) "The Phantom Menace: Urban Renewal in Berlin and the Aestheticisation of Politics". Paper presented at the annual meeting of the American Sociological Association. Atlanta, 1-19. 
Nasr, J.L. (1996) "Beirut/Berlin: Choices in Planning for the Suture of Two Divided Cities", Journal of Planning Education and Research, Vol. 16, No. 1, pp. 27-40.

Safier, M. (1997) “Managing Division”, City, Vol. 2, No. 8, pp. 188-190.

Schwedler, H. (2000) "A City Twice Unique: The Urban Planning Context in Berlin". Eds.: W. J. V. Neill and H.-U. Schwedler, (editors) Urban Planning and Cultural Inclusion: Lessons from Belfast and Berlin, New York, Palgrave, pp. 24-34.

Sterrett, K., Hackett, M., Hill, D. (2011) “Agitating for a De- sign and Regeneration Agenda in a Post-Conflict City: The Case of Belfast", The Journal of Architecture, Vol. 16, No. 1, pp. 99-119.

Von Beyme, K. (1990) "Reconstruction in the German Democratic Republic". Ed.: Diefendorf, J. M. (editor) Rebuilding Europe's Bombed Cities, Macmillan, pp. 190-208.

\section{Internet References}

Url-1 http://www.belfastinterfaceproject.org/ [Date accessed 20 August 2015] 